\title{
A Study on the Feasibility of Total Quality Management Model and the Awareness and Attitude of the Managers of Health Care
}

\author{
Fereshteh Farzianpour ${ }^{1 *}$, Kazem Mohammad ${ }^{2}$, Abbas Rahimi Foroushani2 ${ }^{*}$, \\ Samira Alirezaei ${ }^{3}$, Fatemeh Manafi ${ }^{1}$ \\ ${ }^{1}$ Department of Health Management and Economics, School of Public Health, Tehran University of Medical \\ Sciences, Tehran, Iran \\ ${ }^{2}$ Department of Epidemiology and Biostatistics, School of Public Health, Tehran University of Medical Sciences, \\ Tehran, Iran \\ ${ }^{3}$ School of Health Management and Information Sciences, Iran University of Medical Sciences, Tehran, Iran \\ Email: farzianp2@yahoo.com, mohamadk@tums.ac.ir, ${ }^{*}$ rahimifo@tums.ac.ir, s.alirezaei.6856@gmail.com, \\ famanafi@yahoo.com
}

Received 21 December 2014; accepted 14 February 2015; published 16 February 2015

Copyright (C) 2015 by authors and Scientific Research Publishing Inc. This work is licensed under the Creative Commons Attribution International License (CC BY). http://creativecommons.org/licenses/by/4.0/

c) (†) Open Access

\section{Abstract}

Total Quality Management is not just an admirable phenomenon but it is any client's right and can be done through contribution of the staff and the managers as well as the client's of an organization. The purpose of the present study is to investigate the feasibility of TQM model and the attitude of the managers of health field of Yazd medical sciences university towards it. The present study was a descriptive and analytical one which was cross-section ally conducted from 2010 to 2011. The population under study consisted of the managers of the unit of staff vice-chancellor for health and treatment, the managers of health system and centers of cities and also the managers of Yazd's public hospitals. 64 people were chosen using the formula for calculating the number of samples. A questionnaire with 48 questions was used. The questionnaire's validity was approved by the faculty members whose major is management and its reliability by using $\alpha$-cronbach $87 \%$. To analyze the data, the software SPSS V.17 was used. Scoring method was based on likert. The findings of the study show that, considering feasibility of TQM, there is a significant relation between the awareness and attitude of the managers of health and treatment field on one side and the variables, age and University degree, on the other side $p=0.001$. Considering binary logistic regression and the results obtained in the form of inter and backward stepwise, the most important factors affecting the feasibility of TQM among the managers of health and treatment field are the level of awareness and attitude with the predicted accuracy $79.3 \%$ and $87.9 \%$ respectively.

"Corresponding authors.

How to cite this paper: Farzianpour, F., Mohammad, K., Foroushani, A.R., Alirezaei, S. and Manafi, F. (2015) A Study on the Feasibility of Total Quality Management Model and the Awareness and Attitude of the Managers of Health Care. Health, 7, 231-237. http://dx.doi.org/10.4236/health.2015.72027 


\section{Keywords}

\section{Feasibility, Total Quality Management Model, Awareness, Attitude, Managers of Health Field}

\section{Introduction}

Total quality management (TQM) has a great potential to address quality Problems in a wide range of industries and improve the organizational Performance [1].

Concerning health services, quality has a special place since the great mission of maintaining and taking care of community health is undertaken by this system [2]. In addition, hospitals which offer health and care services are the inseparable part of the health system. Hospitals, although constituting a small part of the health system, considering their number, are viewed as its most important part/element, as a significant part of expenditure on health is related to them [3].

TQM is a suitable way to relatively achieve efficiency and effectiveness which in turn leads to achievements such as success in long term, meeting the workers', customers' and other interested parties' needs in the society [3]. It is what can, as a key and efficient means, give a practical aspect to the total quality management and change it from being merely theoretical [2] [4].

The role of the managers in quality is so essential. They should be the first ones who try to improve quality, recognizing both the usual and special causes and distinguishing them from each other [3].

The quality management involves 8 principles which the executive manager of any organization can use to direct his organization in order to improve the performances. The principles are as follows: focusing on clients, leadership in management, workers' contribution, procedural approaches, systematic approach to management, continuous improvement, decision making based on facts and beneficial and mutual relationship to the providers [4] [5].

TQM is one of the most important changes which have taken place in the field of health care management. After fields such as industry and business, it is now the turn of health field to benefit from TQM in principle. The ministry of health, treatment and medical education has chosen TQM as a comprehensive and applied strategy since 1998 to achieve administrative development and improve the quality of services in order to respond to the needs and expectations of the society. It is worth mentioning that the national committee of improving quality known as an educational-consultative committee to educate, direct and support the programs concerning quality improvement has started its work [6].

In fact, the purpose of TQM is optimizing human powers and improving the quality of patient care through establishing the system in the wards [7]. TQM is not regarded as the final process of improvement, but everyone should try to achieve it and view improvement as a continuous process [8] [9].

Despite the undeniable advantages of TQM for an organization, there is no consensus about its framework, but there is a general consensus about the need for a systematic method or framework in order to make TQM feasible [10]. Concerning this matter, it can be said that patterns excellence such as the European-base pattern of TQM and Baldridge organizational improvement pattern and the operational patterns derived from them involve the presuppositions of TQM and the results of various studies indicate that they are a suitable framework to direct the systematic establishment of TQM as well as its evaluation in the organization [10]-[12].

In this study, we decided to examine the feasibility of TQM and the attitude of the health managers of Yazd medical sciences university towards it.

\section{Methods}

The present study is a descriptive-analytic one which was carried out cross-section ally in order to examine the attitude of the health general staff managers of Yazd medical sciences university, including those of the health nets and centers and also managers of hospitals of 10 health nets as well as the managers of health vice-chancellor of University.

The study was approved by the Ethics Committee of Tehran University of Medical Sciences (TUMS) IRB No. 88197-19/7/2011 and by the Ethics Committee of the Management College, Yazd University of Medical Sciences, Iran. The researchers described the purpose of the study and Potential risks/benefits to the health centers' 
managers and all the prospective participants. All subjects were required to sign consent form.

The tool used to gather data was a questionnaire consisting of 48 questions. Its validity has been proved by university professors and its reliability based on the method of calculating and Cronbach coefficient is $87 \%$. The way used to score the questions was based on Likert scale. Awareness level of the participants in the study was divided into 5 levels: excellent, good, average, weak and very weak. Based on the scores acquired by each participant in the study, they were categorized to 5 levels (from 0 to 100). The attitude was examined in the same way and all the data were analyzed using the software SPSS V.18. The study population included 64 individuals. Finally, the information pertaining to 58 managers was gathered.

\section{Findings}

\subsection{Descriptive Findings}

The area of activity of the managers was as follows. From health field 42 (71.4\%) and 16 (28.6\%) from treatment field. Concerning education, 29 (50\%) had B.S., 4 (6.9\%) M.S. and 25 (43.1\%) PhD. The youngest was 30 years old and the oldest 49 years (Table 1 ).

Table 1. Frequency distribution of awareness level, mangers' attitude towards TQM and feasibility of TQM, considering area of activity, age, education of the mangers of the health field of Yazd Medical Sciences University.

\begin{tabular}{|c|c|c|c|c|c|c|c|}
\hline \multirow{2}{*}{$\begin{array}{l}\text { 1. Level of } \\
\text { awareness }\end{array}$} & \multirow[b]{2}{*}{ Variable } & \multicolumn{2}{|c|}{ Good awareness } & \multicolumn{2}{|c|}{ Average awareness } & \multirow{2}{*}{ Test } & \multirow{2}{*}{ P-value } \\
\hline & & $\mathrm{N}$ & $\%$ & $\mathrm{~N}$ & $\%$ & & \\
\hline \multirow{2}{*}{ Area of activity } & Health & 30 & 71.4 & 12 & 28.6 & \multirow{2}{*}{$\begin{array}{c}\text { Fisher careful } \\
\text { test }\end{array}$} & \multirow{2}{*}{0.343} \\
\hline & Treatment & 13 & 81.3 & 3 & 18.8 & & \\
\hline \multirow[b]{2}{*}{ Age } & Below 40 & 14 & 66.7 & 7 & 3 & \multirow[b]{2}{*}{ Chi-square test } & \multirow[b]{2}{*}{0.328} \\
\hline & Above 41 & 29 & 78.4 & 8 & 21.6 & & \\
\hline \multirow{2}{*}{$\begin{array}{l}\text { Level of } \\
\text { education }\end{array}$} & B.S. & 22 & 75.9 & 7 & 24.1 & \multirow{2}{*}{ Chi-square test } & \multirow{2}{*}{0.764} \\
\hline & M.S. and $\mathrm{PhD}$ & 21 & 72.4 & 8 & 27.6 & & \\
\hline \multirow{2}{*}{$\begin{array}{l}\text { 2. Level of } \\
\text { attitude }\end{array}$} & & \multicolumn{2}{|c|}{ Good attitude } & \multicolumn{2}{|c|}{ Average attitude } & & \\
\hline & Variable & $\mathrm{N}$ & $\%$ & $\mathrm{~N}$ & $\%$ & $103 \mathrm{t}$ & r-value \\
\hline \multirow{2}{*}{ Area of activity } & Health & 35 & 83.3 & 7 & 16.7 & \multirow{2}{*}{$\begin{array}{c}\text { Fisher careful } \\
\text { test }\end{array}$} & \multirow{2}{*}{0.523} \\
\hline & Treatment & 14 & 87.5 & 2 & 12.5 & & \\
\hline \multirow{2}{*}{ Age } & Below 40 & 18 & 85.7 & 3 & 14.3 & \multirow{2}{*}{$\begin{array}{c}\text { Fisher careful } \\
\text { test }\end{array}$} & \multirow{2}{*}{0.581} \\
\hline & Above 41 & 31 & 83.8 & 6 & 16.2 & & \\
\hline \multirow{2}{*}{$\begin{array}{l}\text { Level of } \\
\text { education }\end{array}$} & B.S. & 24 & 82.8 & 5 & 17.2 & \multirow{2}{*}{$\begin{array}{c}\text { Fisher careful } \\
\text { test }\end{array}$} & \multirow{2}{*}{0.500} \\
\hline & M.S. and $\mathrm{PhD}$ & 25 & 86.2 & 4 & 13.8 & & \\
\hline \multirow{2}{*}{$\begin{array}{l}\text { 3. Level of } \\
\text { feasibility }\end{array}$} & & \multicolumn{2}{|c|}{ Feasible } & \multicolumn{2}{|c|}{ Infeasible } & & \\
\hline & variable & $\mathrm{N}$ & $\%$ & $\mathrm{~N}$ & $\%$ & & \\
\hline \multirow{2}{*}{ Area of activity } & Health & 31 & 73.8 & 11 & 26.2 & \multirow{2}{*}{$\begin{array}{l}\text { Fisher careful } \\
\text { test }\end{array}$} & \multirow{2}{*}{0.089} \\
\hline & Treatment & 15 & 93.8 & 1 & 6.3 & & \\
\hline Aop & Below 40 & 16 & 76.2 & 5 & 23.8 & Fisher careful & 0.451 \\
\hline & Above 41 & 30 & 81.1 & 7 & 18.9 & test & \\
\hline Level of & B.S. & 23 & 79.3 & 6 & 20.7 & Chi-sculare test & 1 \\
\hline education & M.S. and $\mathrm{PhD}$ & 23 & 79.3 & 6 & 20.7 & 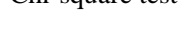 & 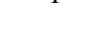 \\
\hline
\end{tabular}




\subsection{Analytical Findings}

The mean percentage of the managers' scores concerning the questions on awareness' of TQM was 71.9 \pm 8.7. Based on the scores acquired, the managers were divided into three groups, i.e. weak, average and good.

The weak ones included those whose score was less than $33.3 \%$, the average between $33.4 \%$ and $66.6 \%$ and the good ones above $66.7 \%$. The results indicated that nine of the managers (15.5\%) had an average attitude and 49 (84.5\%) a good attitude towards TQM. There was no manager with a weak attitude (Table 2). In total, 12 of the managers (20.7\%) believed that TQM was not feasible in their organization and 46 (79.3\%) considered it feasible (Table 3). Considering the feasibility of TQM, in order to examine the relationship between variables, Binary Logistic Regression was used. The results are shown in the form of Inter and Backward stepwise in Table 4 and Table 5. In view of this model, there is no relationship between the feasibility of TQM and the level of managers' education and age. So these variables are omitted from the model. Variables related to the level of awareness, attitude and field of study in logistic Regression model are shown in Table 5 in the form of Backward stepwise. The accuracy of prediction of this model is $79.3 \%$.

Also in order to examine the relationship between the variables and the manager's attitude towards TQM, Binary logistic Regression was used. The results are shown in the form of Inter and Backward stepwise.

The results indicate that there is no relationship between the managers' attitude towards TQM and level of

Table 2. Frequency distribution of managers’ attitudes towards TQM considering their level of their awareness.

\begin{tabular}{|c|c|c|c|c|c|}
\hline \multirow{2}{*}{$\begin{array}{l}\text { Level of } \\
\text { awareness }\end{array}$} & \multicolumn{2}{|c|}{ Average awareness } & \multicolumn{2}{|c|}{ Good awareness } & \multirow{2}{*}{ P-value } \\
\hline & $\mathrm{N}$ & $\%$ & $\mathrm{~N}$ & $\%$ & \\
\hline Average attitude & 7 & 46.7 & 2 & 4.7 & \multirow{2}{*}{0.001} \\
\hline Good attitude & 8 & 53.3 & 41 & 95.3 & \\
\hline
\end{tabular}

Table 3. Frequency distribution of TQM feasibility from the point of view of the managers considering their level of awareness and their attitude towards TQM.

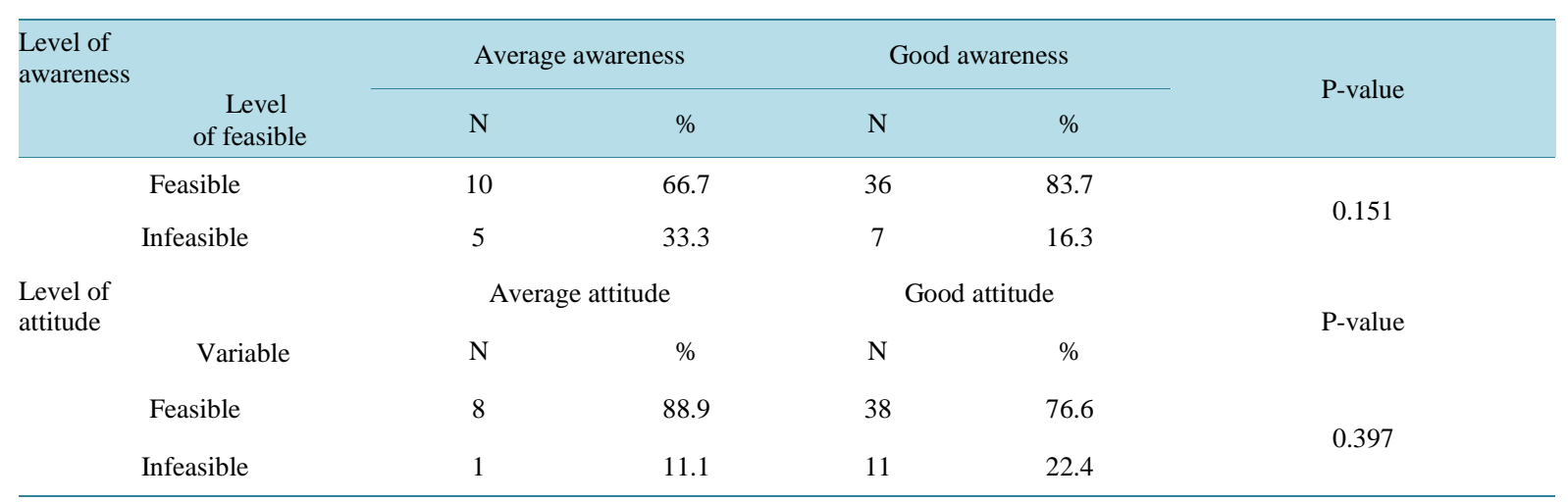

Table 4. The relationship between variables of the study and feasibility of TQM using logistic regression in the form of inter and backward stepwise.

\begin{tabular}{|c|c|c|c|c|c|c|c|c|}
\hline \multirow{2}{*}{ Variable } & \multirow{2}{*}{$\begin{array}{c}\text { Variable } \\
\text { coefficient } \\
\text { (B) }\end{array}$} & \multirow{2}{*}{$\begin{array}{c}\text { Standard error } \\
\text { (S.E.) }\end{array}$} & \multirow{2}{*}{ Wald } & \multirow{2}{*}{$\begin{array}{l}\text { Degree of } \\
\text { freedom } \\
\text { (df) }\end{array}$} & \multirow{2}{*}{ P. value } & \multirow{2}{*}{ Odds } & \multicolumn{2}{|c|}{ Odds 95\% } \\
\hline & & & & & & & $\begin{array}{c}\text { Limits below } \\
\text { odds }\end{array}$ & $\begin{array}{c}\text { Limits above } \\
\text { odds }\end{array}$ \\
\hline Level of awareness & 1.49 & 0.893 & 2.77 & 1 & 0.095 & 4.43 & 0.77 & 25.55 \\
\hline Level of attitude & 2.44 & 1.481 & 2.72 & 1 & 0.099 & 11.52 & 0.63 & 2.0 \\
\hline Level of education & 1.04 & 0.847 & 1.53 & 1 & 0.216 & 2.82 & 0.54 & 15.02 \\
\hline Age & 0.152 & 0.086 & 3.07 & 1 & 0.08 & 1.16 & 0.98 & 1.37 \\
\hline Field of study & 2.57 & 1.290 & 3.97 & 1 & 0.046 & 13.1 & 1.04 & 164.1 \\
\hline
\end{tabular}


Table 5. The relationship between the study variables and the feasibility of TQM using backward stepwise logistic regression.

\begin{tabular}{ccccccccc}
\hline Variable & $\begin{array}{c}\text { Variable } \\
\text { coefficient (B) }\end{array}$ & $\begin{array}{c}\text { Standard error } \\
\text { (S.E.) }\end{array}$ & Wald & $\begin{array}{c}\text { Degree of } \\
\text { freedom (df) }\end{array}$ & P. value & Odds & $\begin{array}{c}\text { Limits below Limits above } \\
\text { odds }\end{array}$ \\
\hline Level of awareness & 1.689 & 0.859 & 3.839 & 1 & 0.05 & 5.385 & 0.999 & 29.019 \\
Level of attitude & 2.119 & 1.306 & 2.633 & 1 & 0.105 & 8.319 & 0.644 & 107.51. \\
Field of study & 1.773 & 1.134 & 2.442 & 1 & 0.118 & 5.886 & 0.637 & 54.36 \\
\hline
\end{tabular}

their education, age and their field of activity/study, so these variables are omitted from the model. The variables, the managers' level of awareness and the feasibility of TQM are present in Logistic Regression in the form of Backward stepwise. The prediction accuracy of the model is $87.9 \%$.

\subsection{Discussion and Data Analysis}

In examining the feasibility of TQM and its relation with level of education, 23 of the managers with B.S. degree and 23 of those with M.S. degree or PhD consider TQM feasible. So there is no significant relation between different levels of education and feasibility of TQM.

Considering the results of the study, there is no significant relation between the levels of education of those who work in staff section and their awareness of and attitude towards the feasibility of T.Q.M.

In a study conducted to analytically examine the extent to which the faculty board (professors and managers) are ready to accept TQM, none of the participants (220 professors and managers) had negative attitude. 14.54\% of them had positive attitude and $84.46 \%$ rather positive.

Also, there was no significant difference between the three faculty departments concerning TQM acceptance, but there was a significant difference between professors and managers concerning TQM acceptance [16]. In another study concerning awareness of and applying TQM principles by managers of area 2 of Ministry of education .The results indicated that there was a significant difference between the managers and teachers; the managers had a positive attitude towards TQM model [17].

In a study conducted to find the relation between educational level of managers of Kohkiolyeh's high schools and acceptance of TQM model, the results showed that there was no significant relation between the two [18] [19].

A study was conducted to examine the attitude of the managers and faculty board of Oromiyeh University towards TQM model and its relationship to demographic characteristics [3] [6].

\section{Conclusion}

Considering the results of the study, there is no significant relation between the levels of education and age of those who work in staff section and their awareness of and attitude towards the feasibility of TQM. The result of the study showed that there was a significant difference between the managers' attitude and that of the faculty board. There was also a significant relation between the faculty boards' major and indices of management commitment, client-orientated attitude, using information and education.

\section{Competing Interests}

The authors declare that they have no competing interests.

\section{Authors' Contributions}

FF selected the topic and designed the study, analyzed the data, interpreted the findings, wrote the first draft of the manuscript and revised the manuscript; KM \& ARF selected the topic and designed the study, analyzed the data, interpreted the findings, commented on the first draft of the manuscript and revised the manuscript; KM \& ARF designed the study, analyzed the data, interpreted the findings and commented on the first draft of the manuscript; SH designed the study, analyzed the data, interpreted the findings and commented on the first draft of 
the manuscript; SA \& FM \& SHH designed the study, analyzed the data, interpreted the findings and commented on the first draft of the manuscript. All authors read and approved the final manuscript.

\section{Acknowledgements}

This study was a part of a MPH thesis supported financially by Tehran University of Medical Sciences; according to contract number 10,495 dated May 23, 2010. We appreciate the efforts by the personnel of healthcare centers in the city of Yazd who play a key role in controlling health care management and in improving health standards in the society.

\section{References}

[1] Jackson, S. (2000) Successfully Implementing TQM within Health Care. International Journal of Health Care Quality Assurance (IJHQA), 14, 157-163. http://dx.doi.org/10.1108/09526860110392431

[2] Hasan Zade, M. and Najafgholi Nezhad, A. (2008) Assessment and Evaluation of Libraries and Information Centers: Theories and Methods and Tools. Information Science \& Technology, 25, 131-152. [In Persian]

[3] Hashemi, A. (2003) Changing Key in Management and Leadership. Nazir, Iran. [Book in Persian]

[4] International Organization for Standardization, Editors (2009) Quality Management Principles [Monograph on the Internet]. Geneva. http://www.iso.org/

[5] Farzianpour, F., Rahimi Fouroshani, A., Kamjoo, H. and Hosseini, S.S.H. (2011) Organizational Citizenship Behavior (OCB) among the Managers of Teaching Hospitals. American Journal of Economics and Business Administration, 3, 534-542. http://dx.doi.org/10.3844/ajebasp.2011.534.542

[6] Farzianpour, F., Rahimi Fouroshani, A., Beyzaiee, S. and Hosseini, S. (2012) Evaluation of the Selfesteem Managers in Clinical Wards of Hospitals Affiliated to Tehran University of Medical Sciences. World Applied Sciences Journal, 16, 686-692.

[7] Bruner, L.S. and Sudarth, D.E. (2004) Internal-Surgery Nursing. Moradi, A., Translator. Afrang, Tehran. [Persian]

[8] Farzianpour, F., Roholah Askari, R., Torabipoor Hamedani, A., Khorshidi, G.H. and Amirifar, S. (2011) Accreditation of Emergency Department at a Teaching Hospital in Tehran University of Medical Sciences in 2010. American Journal of Economics and Business Administration, 3, 498-505. http://dx.doi.org/10.3844/ajebasp.2011.498.505

[9] Farzianpour, F., Hosseini, S., Mirsepasi, A., Honary, H., Hosseini, S.S. and Hosseini, S. (2013) Internal Evaluation of the Department of Environmental Health Science and Engineering. American Journal of Applied Sciences, 10, 58-63. http://dx.doi.org/10.3844/ajassp.2013.58.63

[10] Bou-Llusar, J.C., Escrig-Tena, A.B., Roca-Puig, V. and Beltrán Martín, I. (2009) An Empirical Assessment of the EFQM Excellence Model: Evaluation as a TQM Framework Relative to the MBNQA Model. Journal of Operations Management, 27, 1-22. http://dx.doi.org/10.1016/j.jom.2008.04.001

[11] Farzianpour, F., Geray, S., Rahimi Foroushan, A., Arab, M. and Hosseini, S.H. (2013) Evaluating the Average Access to Care and Continuity of Care Patients in Tehran Teaching Hospitals. Health, 5, 2110-2115. http://dx.doi.org/10.4236/health.2013.512288

[12] van der Wiele, A., Williams, A.R.T. and Dale, B.G. (2000) ISO 9000 Series Registration to Business Excellence: The Migratory Path. Business Process Management Journal, 6, 417-427. http://dx.doi.org/10.1108/14637150010353911

[13] Westlund, A.H. (2001) Measuring Environmental Impact on Society in the EFQM System. Total Quality Management, 12, 125-135. http://dx.doi.org/10.1080/09544120020010147

[14] Eskildsen, J.K. and Dahlgaard, J.J. (2000) A Causal Model for Employee Satisfaction. Total Quality Management, 11, 1081-1094. http://dx.doi.org/10.1080/095441200440340

[15] Prabhu, V., Appleby, A., Yarrow, D. and Mitchell, E. (2000) The Impact of ISO 9000 and TQM on Best Practice/Performance. The TQM Magazine, 12, 84-92. http://dx.doi.org/10.1108/09544780010318334

[16] Heidari Gorji, A.M. and Farooquie, J.A. (2011) A Comparative Study of Total Quality Management of Health Care System in India and Iran. BMC Research Notes, 4, 566. The Electronic Version of This Article Is the Complete One and Can Be Found Online. http://www.biomedcentral.com/1756-0500/4/566

[17] Farzianpour, F, Emami, A.H., Davari-Tanha, F., Hosseini, S. and Farzanehnejad, A.R. (2010) Educational Programs’ Quality Assessment Based on Graduates’ Comments. IRCMJ, 12, 302-307.

[18] Farzianpour, F., Dargahi, H., Hosseini, S., Hosseini, S.S. and Hosseini, S. (2011) Program Evaluation of Health Care Management: Is It Adjusted for Students Needs? American Journal of Economics and Business Administration, 3, 420424. http://dx.doi.org/10.3844/ajebasp.2011.420.424 
[19] Farzianpour, F., Dargahi, H., Eynolahi, N. and Aghababa, S. (2010) Evaluation in Department of Health Care Management in Faculty of Allied Medical Sciences Tehran University of Medical Sciences. Health Information Management, 7, 353-360. www.jhim.ir

[20] Farzianpour, F., Aghababa, S., Delgoshaei, B. and Haghgoo, M. (2011) Performance Evaluation a Teaching Hospital Affiliated to Tehran University of Medical Sciences Based on Baldrige Excellence Model. American Journal of Economics and Business Administration, 3, 272-276.

[21] Farzianpour, F., Mhammad, K., Malekafzali, H. and Nedjat, S. (2014) Determining the Quality of Management and Structural Elements of the Epidemiology and Biostatistics Department in Tehran University of Medical Sciences. Journal of Service Science and Management, 7, 430-439. http://dx.doi.org/10.4236/jssm.2014.76040 
Scientific Research Publishing (SCIRP) is one of the largest Open Access journal publishers. It is currently publishing more than 200 open access, online, peer-reviewed journals covering a wide range of academic disciplines. SCIRP serves the worldwide academic communities and contributes to the progress and application of science with its publication.

Other selected journals from SCIRP are listed as below. Submit your manuscript to us via either submit@scirp.org or Online Submission Portal.
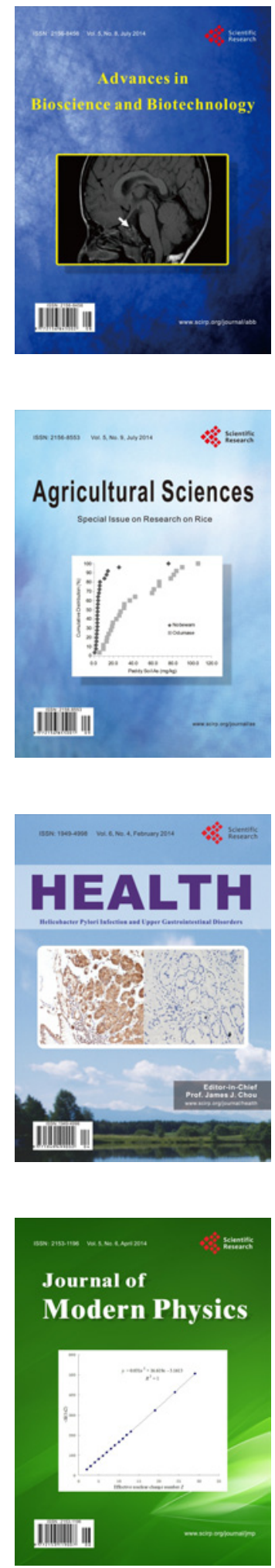
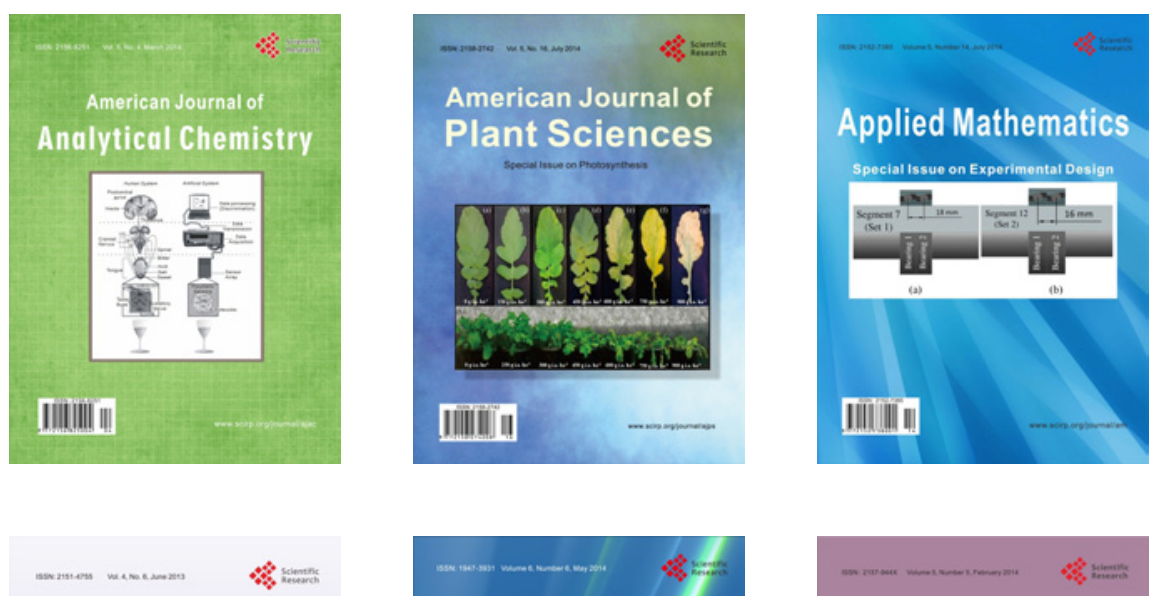

Creative Education
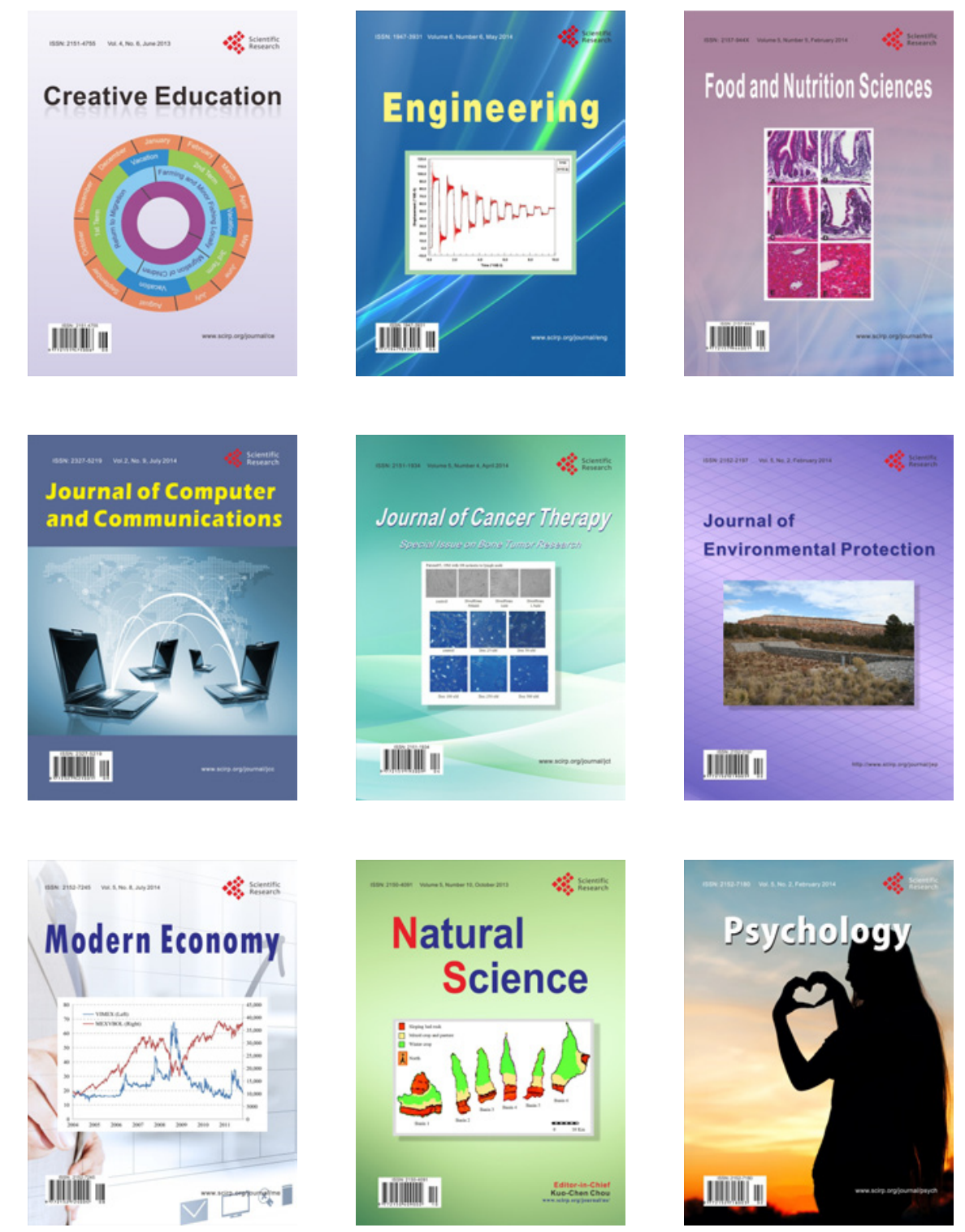